\title{
WILLINGNESS TO PAY FOR NOISE REDUCTION IN RESIDENTIAL AREAS AFFECTED BY AIRPORT TRAFFIC: THE CASE OF BARCELONA.
}

\author{
Carlos Marmolejo DUARTE 1 \\ CENTRE OF LAND POLICY AND VALUations \\ POLYTECHNiC UniVERSITY OF CATALONIA
}
Presented at The 15 Th Annual Congress of the European Real Estate Society, Cracow 18-21 June 2008.

\begin{abstract}
.
This paper reports the results of a research designed to assess the impact of Barcelona's airport extension in terms of noise increase. A contingent valuation (CV) approach was carried out in order to extract the stated preference for noise reduction for a representative sample of residential areas; using this technique the respondents revealed their willingness to pay (WTP) for a proposed noise reduction. One of the main problems of $\mathrm{CV}$ is the protest answers, it is to say, the people that do not reveal their WTP, although they do value positively the good offered. For this reason two approaches were tested: the first is the conventional one where people state directly their WTP for a specific noise reduction; the second one the interviewed people state their hypothesis of real estate revalorization in case that such noise reduction would occur. The results reveals that direct WTP has a protest rate of $37.19 \%$, meanwhile the second indirect WTP has only a protest rate of $7.8 \%$. Furthermore, the data analysis based on logistic models suggest two conclusions: 1) the higher is the knowledge of the problem related to noise source, the higher is the WTP, controlling the rest of variables, and 2) also higher is the level of protest rate. It is to say, people aware of the airport problems are more skeptical about the valuation process (e.g.: the solution proposed to reduce the noise, the payment vehicle, or the noise reduction offered), this skepticism drive to boycott the experiment and consequently it masks the true WTP. Both effects produce a reduction on the aggregated mean WTP. For this reason the opinion and valuation of an environmental good (as silence) is not only influenced by the individual perception, but also is influenced by the knowledge about it, and the social perception; for this latter reason the predictive capacity of models is improved when the socio-spatial correlation interactions are solved. Finally the results also suggest that the impact of airport noise is also influenced by the existence of other environmental noise source and the configuration of urban fabrics.
\end{abstract}

KEY WORDS: noise assessment, airport noise, environmental economics, contingent valuation.

\footnotetext{
${ }^{1}$ carlos.marmolejo@upc.edu
} 


\section{REVEALED AND STATED PREFERENCES AS A WAY TO ASSESS THE NOISE IMPACT ON QUALITY OF LIFE.}

Noise impacts negatively people's welfare, not only because it disturbs the daily activities, but mainly because it has a direct impact on, both physic and psycho health. In economics terms it produces a damage function (Navrud, 2002). In environmental economics two are the approaches to economically quantify such an injury: revealed preferences and stated preferences.

Stated preferences try to find the equivalent or compensatory variation associated to changes on welfare level. So, it tries to extract people's willingness to pay (WTP) when the utility level increases (or potentially increases) as a consequence of an environmental improvement (e.g.: noise reduction). On the contrary willingness to accept (WTA) is used to asses a reduction on utility level produced (or potentially produced) by an impoverishment of environmental quality. In the family of stated or declared preferences contingent valuation (CV) is the most popular technique (Riera, 1994). CV emulates a hypothetic market where public goods or services (like silence) are traded, in this market, researchers offer a change on environmental quality (e.g.: an eventual reduction of $10 \mathrm{~dB}$ A of street noise), and try to find the WTP for said improvement. Frequently, practitioners and scholars have a skeptical opinion about the hypothetical foundations of the method, arguing that people may not have the same behavior when are confronted to real decisions; nevertheless the Blue-Ribbon Report of the US National Oceanic and Atmospheric Administration has dissipated some economical doubts, amending its use, in the environmental economics framework. Nonetheless in the case of noise evaluation the $\mathrm{CV}$ has not been fairly applied. Theoretically, WTP or WTA allows calculating the marginal utility of the good or service assessed. Since CV deals with a hypothetic market it results highly versatile and can be used to evaluate real or potential projects. Besides CV allows to find directly the marginal utility of non-use values (opportunity, existence, permanence) which simply cannot be estimated by means of other methodologies. As it is evident in order to implement a CV study it is necessary to make a statistically representative sociological survey. After having collected people's WTP or WTA data can be econometrically analyzed in order to find the marginal value of noise annoyance.

The revealed preferences are the alternative family used to assess the value of public goods and services. Belonging to this family is the hedonic price method (HP), which is the most used. HP is based on the assumption that market value of private goods or services internalize the value of environmental goods or services. Using econometric techniques it is possible to infer the marginal value of environmental goods, when all the other attributes that influence market prices are suitably controlled. Normally the real estate prices, and namely the residential prices, are used when 
evaluating the impact of noise on quality of life. Since it is assumed that willingness to pay for houses trades off the environmental quality, in order to maintain the same utility level among residents and locations.

As it has been exposed both methodologies deal with the same aim, that is, to find the economic value that compensates the change on the welfare level produced by a level change on the provision of public goods or services. Nevertheless these approximations do have some important differences, see for example Brookshire et al. (1982).

\section{STATED PREFERENCES ON THE AIRPORT NOISE IMPACT, SHORT REVIEW.}

In the literature the use of CV in the assessment of noise impact has been, as commented before, very limited. According to Navrud (2002) one the pioneering studies was carried out by Opschoor in 1988 in Switzerland, in 1995 Thune-Larsen studied, using CV and Conjoint Analysis (another stated preferences method), the noise impact on Oslo's residential surroundings. In the Paris Orly airport Faburel (2002) found, using CV applied to 607 persons, that WTP was explained by the stated annoyance, but also WTP increased when surveyed people lived in detached houses; other aspects influencing WTP were the income level and disinformation about the problematic associated to the airport noise. Feitelson et al. (1996) have carried out a comprehensive study in three cities (not specified in their paper), they found that NDSI adopted values of $2.4 \%-4.1 \%$ for proprietors, and $1.8-3.0 \%$ for renters. NDSI is the acronym of Noise Depreciation Sensitivity Index designed by Walters (1975). This index measures the impact on real estate prices of each unit of noise level. A NDSI equal to $1 \%$ means that price decreases an average of $1 \%$ for each point that noise increase (e.g.: dB.). Recently, Bristow \& Wardman (2006) have found that WTP vary according to the nuisance level experienced along the week. So, annoyed people affected by weekend and night noise have a higher WTP. A novelty methodology based on the happiness self-perceived of respondents has been recently suggested by Van Praag and Baarsma (2005). According to them, after controlling the subjective conditions of residents, the perceived condition in terms of happiness, may be linked to environmental quality of life, included the airport noise nuisance. When the Barcelona's airport was going to be expanded, Riera and Macian (1999) studied the only, as far as we know, CV study for this case. According to them only $16 \%$ of 800 total surveyed people, along Barcelona's Metropolitan Region, agreed to compensate households affected by airport enlargement. In terms of 2007 Euros, respondents stated, as an average, a compensation of 1.266 Euros for household. 


\section{BARCELONA'S AIRPORT ENLARGEMENT.}

At 1994 begun the plans to expand the Barcelona's metropolitan airport; after some alternatives proposed to decentralize empowering or creating a new air platform elsewhere did not succeeded, the final decision was to enlarge the original infrastructure settled in the neighbor municipality of $\mathrm{El}$ Prat de Llobregat. After several options were evaluated the Commission, settled to manage the enlargement project, decided to build a new runway parallel to the largest original, as well as a new terminal building. This new runway was located in the extreme south position, as far as possible, from the largest original runway, in order to allow a simultaneous functioning, and consequently, to maximize in number the landings and takes offs.

FIGURE 1 BARCELONA'S AIRPORT SONIC FOOTPRINTS AND SURVEYED AREAS

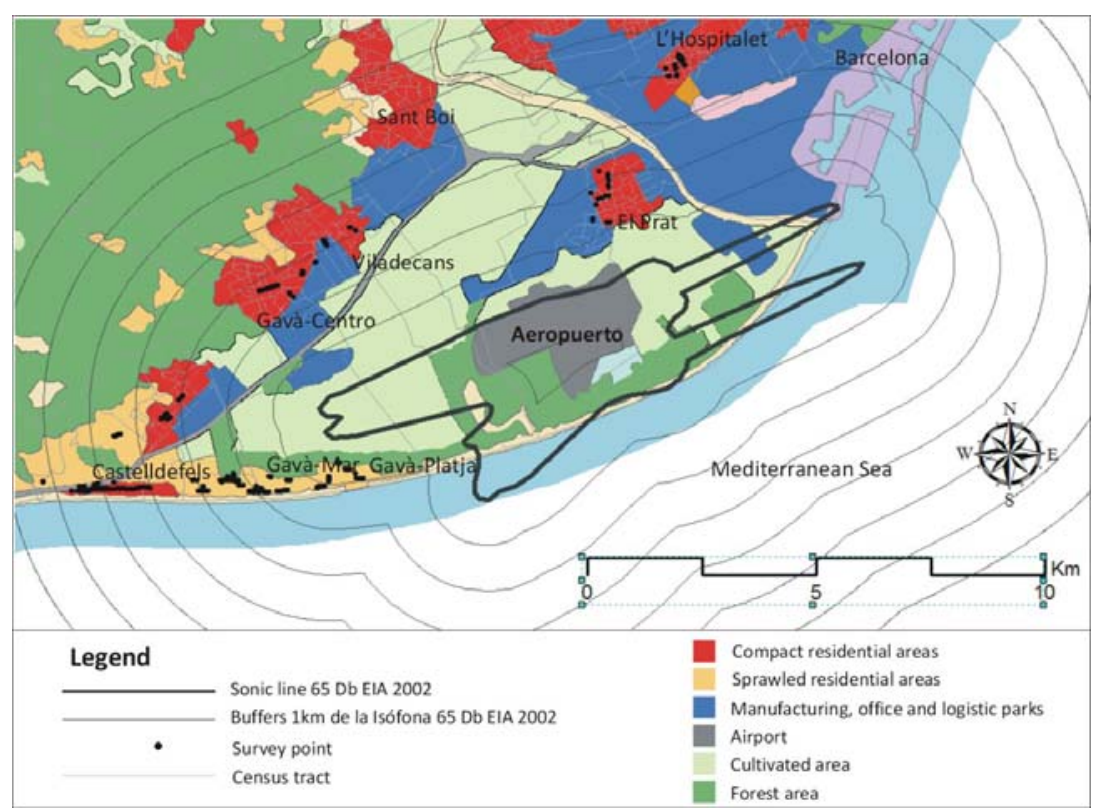

The original landing and take off air corridors were designed without considering the opinion of local residents; the said approach corridor invaded partially the residential surrounding areas. Nevertheless the protests were in increment, as the negative effects produced by the increase of noise were patent. As a consequence in October 2004, after the new runway aperture, a global and temporal (until 2012) agreement between the Commission and local agents was reached. This negotiation agrees the use of runways in a different way as it was originally planned. Firstly the independent use of runways (each runway is used to land and take off independently) was substituted by a segregated use (one runway is used to land and the other to take off), which according to experts may reduce the planned number of travelers. Secondly air approach corridors were modified. As a matter of fact, 
in the most usual configuration, planes taking off by the new runway do turn 60 으 to the right (towards the sea) as soon as they take off.

Social mobilization again the negative effects of airport enlargement derivate in the radicalization or creation of new local associations representing resident's interests. A number of them have been highly active in the formulation of the current configuration. Some independent studies carried out by such associations have argued that noise levels reached up $100 \mathrm{dBA}$ in terms of instantaneously measurement. In this revolted context we tried to find what the willingness to pay (WTP) of residents was in order to benefit from an eventual noise reduction.

\section{Methodological APPROACH.}

Since air corridors configuration changed slightly after opening the new runway in September 2004, this evaluation is complex. The good assessed can be defined as "the noise level increased between 2004 and 2006 (when temporal agreement was reached) and the eventual risk that it may increase again when, in 2012, the configuration agreement ends". As it can be observed what we try to asses is a real change and a potential one. Nonetheless, the residents surveyed were exposed to the noise levels evaluated.

In VC it is necessary to offer a potential change in the quality of environment. In this case, what has been proposed is an eventual reduction of noise levels to those experienced before the 2004's enlargement. For this reason it is necessary to offer a provision vehicle, in this case, we offered the construction of a new runway orientated not to the residential areas, but to the sea. It was considered not convenient to offer a marine runway, as some politicians has proposed, since it may be interpreted as a harmful infrastructure for submarine biotopes.

With this infrastructure the current taking offs may be redirected out from the residential areas, reducing, as a consequence, noise levels. After exposing the provision vehicle and the potential benefits, it is necessary to extract the WTP. In this case it was argued that the cost of the new infrastructure would be paid by national, regional and local authorities. Specifying that local authorities would collect such founds from residents, using specific fees. In Spain there is certain tradition to fund public works with "special contributions", for that reason, using this familiar formula adds some realism to the proposal (Cummings \& Osborne, 1998).

The survey was structured, as suggested by Barreiro et al. (2005), in three sections:

1. Firstly some questions were launched in order to recall people's experience with general and airport specific noise. In this section 
respondents stated the perceived noise annoyance generated by airport noise (on an ordinal basis) and other aspects related to landings and takes offs frequency. Also it was inquired whether or not respondents living under air corridors perceive it as a potential accident source. Levesque (1994) has found that not only volume does affect noise nuisance, but also the periodicity of impacts.

2. Secondly the offered reduction of noise level was explained as well as the provision vehicle. After so, WTP was extracted. In the case that respondents were no WTP they were asked to motive their decision. This latter information was, in the analysis, used to identify protest answers ${ }^{2}$ from true zero values.

3. Finally, some questions about the social, economic and living conditions of people allow having complementary information to be used in the analysis process.

The WTP started in a given value, and if it was accepted, respondents were asked if they were WTP more or less that a higher value (in the negative case, they were asked if they were WTP more or less than a lower vale), the final value opinion was open. Bateman et al. (1995) has suggested that open WTP questions introduce important bias on responses, allowing to increase strategic behavior, that is an overestimation of the assessed asset.

So, we follow a double bounded method with open end. Besides direct-WTP we used a complementary approach (Indirect-WTP), it consisted in asking people about their hypothesis about dwelling price variation in the case that a noise reduction may take place. Respondents chose a quantity among those offered by surveyors.

\section{WILLINGNESS TO PAY, DIRECT APPROACH.}

After validating the information we had $492^{3}$ valid surveys, from this total 309 stated their WTP (including true zero values), so 183 people protested equivalent to $37.19 \%$, which is similar to other comparable studies (Faburel, 2002, had a $49 \%$ protest rate when applied CV to the Orly airport case). According to this 309 valid surveys average WTP is 8.95 Euros/person/month. In order to find the marginal value of an increment of one level of noise annoyance the following model (1) was adjusted.

$$
W T P=B_{o}+\sum_{i=1}^{n} B_{i} X_{i}
$$

\footnotetext{
${ }^{2}$ In a protest answer respondent do not reveal his/her WTP because he/she does not agree the survey, may be because he/she thinks that other should pay or because the proposed provision vehicle is not reliable.

${ }^{3}$ People surveyed were those that at least have 3 years living in the affected area and with at least 18 years.
} 
At (1) $B$ is the adjusting value of the $X$ covariable $i$, being $B_{0}$ the model's constant. Such covariables are information related to people's noise annoyance, income, and other environmental qualities (which were transferred from Census Tract and Corine Land Cover information using a GIS). The best model is MOD-DDP 3, is able to explain up to $33 \%$ of the WTP, and it suggests that on the explanation of WTP significant factors are:

1. Respondent's stated noise annoyance level (ordinal value adopting a scale from 0 to 10)

2. Respondent's, household income level

3. The presence of other noise sources on respondent's neighborhood

4. The fact that respondents live in the area controlled by local resident associations

5. The respondent's real estate revalorization hypothesis.

According to $B$ values WTP increases 0.307 Euros/person/moth as noise nuisance increases each steep. Nonetheless if the resident's house lays at the proximity of a motorway (dichotomous variable), the WTP is reduced 15.17 Euros/person/month; this suggests that noise airport importance has a relative significance: when there are not other sources, it becomes important for people. Other significant finding is the influence that it seems exert the belonging to an associative anti-noise area. This latter finding suggests that beyond personal injury, the WTP is influenced by a high awareness about noise source. This relationship also had been reported by Lenhoop and MacMillan (2007).

TABle 1 WTP explicative model

\begin{tabular}{|c|c|c|c|c|c|}
\hline & & MOD-DP1 & MOD-DP2 & MOD-DP3 & MOD-DP3 GWR \\
\hline Constante & $\begin{array}{l}\text { B } \\
\text { siq. }\end{array}$ & $\begin{array}{l}0,649 \\
0,544\end{array}$ & $\begin{array}{l}0,903 \\
0,392\end{array}$ & $\begin{array}{l}1,006 \\
0,339\end{array}$ & + \\
\hline Niv_ingresos & $\begin{array}{l}\text { B } \\
\text { sig. }\end{array}$ & $\begin{array}{c}1,51 \mathrm{E}-04 \\
0,000\end{array}$ & $\begin{array}{c}1,30 \mathrm{E}-04 \\
0,000\end{array}$ & $\begin{array}{c}1,03 E-04 \\
0,002\end{array}$ & + \\
\hline Mol_vol_son & $\begin{array}{l}\text { B } \\
\text { sig. }\end{array}$ & $\begin{array}{l}0,513 \\
0,000 \\
\end{array}$ & $\begin{array}{l}0,469 \\
0,000 \\
\end{array}$ & $\begin{array}{l}0,307 \\
0,027 \\
\end{array}$ & \\
\hline Zona_asociaciones & $\begin{array}{l}\text { B } \\
\text { sig. }\end{array}$ & & $\begin{array}{l}2,622 \\
0,003 \\
\end{array}$ & $\begin{array}{l}2,146 \\
0,016 \\
\end{array}$ & + \\
\hline Presencia_autopista & $\begin{array}{l}\text { B } \\
\text { sig. }\end{array}$ & & & $\begin{array}{r}-15,176 \\
0,012 \\
\end{array}$ & + \\
\hline Revalorización & $\begin{array}{l}\text { B } \\
\text { sig. }\end{array}$ & & & $\begin{array}{r}1,04 \mathrm{E}-04 \\
0,000\end{array}$ & + \\
\hline
\end{tabular}

\begin{tabular}{lrrrr}
\hline $\mathrm{R}^{2}$ & 0,215 & 0,244 & 0,322 & 0,497 \\
\hline $\mathrm{N}$ & 239 & 239 & 221 & 222 \\
\hline $\mathrm{F}$ & 33 & 25 & 20 & 1,613 \\
\hline Sig. & 0,000 & 0,000 & 0,000 & 0,000 \\
\hline Residuos & 7.916 & 7.624 & $6.235,0$ & 4.633 \\
\hline
\end{tabular}


Model MOD-DP3 GWR is a non-parametric function that uses a geographical weighted regression approach GWR (see Fotheringham et al., 2002) to solve spatial autocorrelation since according to Morans I index there a spatial interrelationships among WTP answers (IM I=0,12, Z score=9,05, sig. 0,001). When WTP is locally weighted regressed, explicative performance increases up to $49 \%$. This noteworthy improvement supports the idea that WTP is a social construction where social imaginary plays an important role on the judgment and assessment of localized prejudices that may bias the CV analysis.

\subsection{MODELING THE PROTEST ANSWERS.}

Some scholars (van Pragg \& Baarsma, 2005) have pointed out the risk to use VC in cases where, like in the Barcelona scenery, respondents are highly sensible to any project proposed. In these cases some bias may be introduced: when using WTC responses may overvalue the injury experience, and when using WTP the people may protest. When comparing the personal conditions of protest answer and non-protest answer some regularity emerge. According to ANOVA test statistical significant differences are the following, people that protested are: 1 ) those more sensible to airplane noise, 2) more annoyed by airplane noise level, 3) more annoyed by take offs frequency, 4) and more annoyed about airplanes crossing their residence areas. As it is evident protest is not randomly distributed along space, rather it concentrates in the areas where people is specially affected by airport noise, this situation masks valuable information, that may underestimate average WTP.

In order to find the explicative factors of protest answers a logit model has been used. Table 2 reports the results, as it is observed, the model is able to explain $65 \%$ of protest answers.

The model reveals that some social, urban and economic factors lie beneath protest answers. So the protest probability augments when: 1) noise annoyance produced by planes increases, 2) when respondents live in low density detached areas, 3) when people does not live in neighbor association " $\mathrm{B}$ ", and 4) when income is low. It is worth to say that urban configuration increases exposure to airport noise as detached houses have an higher external contact than flats, also, low density residence areas are, in general, silence areas, so punctual sounds like those produced by planes play a central role. 


\begin{tabular}{llr}
\hline & & $\begin{array}{c}\text { MOD-P1 } \\
\text { Protesta }\end{array}$ \\
\hline & & \\
\hline \% viv unfiamiliar & B & 3,759 \\
\hline Mol_vol_son & sig. & 0,003 \\
\hline Zona_asociación_"B" & B & 0,120 \\
& sig. & 0,002 \\
\hline Niv_ingresos & B & 0,650 \\
& sig. & 0,038 \\
\hline Constante & B & $-2,29 E-05$ \\
& sig. & 0,012 \\
\hline Pseudo R2 de Negelkerke & B & 1,145 \\
\% de casos 0 correcto & sig. & 0,001 \\
\% de casos 1 correcto & & \\
\% correcto global & & 0,094 \\
N & & 87,70 \\
& & 29,38 \\
Protesta=1 1 & & 65,05 \\
& & 412 \\
\hline
\end{tabular}

\section{WILLINGNESS TO PAY, INDIRECT APPROACH.}

As it has been commented before, in a parallel way, and indirect-WTP was extracted. Respondents were inquired to state their hypothesis of house revalorization in the event that offered noise reduction occurs. From economic theory, ceteris paribus, housing sale price is the capitalization of potential rents. Such rents should reflect the utility level offered, which is influenced, among other factors, by environmental quality (Garcia and Riera, 2003). For that reason there are theoretical founds to expect that direct-WTP is correlated to indirect-WTP. Therefore, if there were not transaction and opportunity costs the sale value of a house should be, partially, a function of direct-WTP.

Firstly it is worthy to say that only $7.8 \%$ of people does not revealed their revalorization hypothesis, which is a noteworthy inferior percentage that direct-WTP protest answers. Revalorization hypothesis average 16,585 Euros, which represents $5.07 \%$ of average sale prices in the area. This value is sharply higher that that found by Riera and Macian (1999) for the same Barelona's airport equivalent to 1,226 Euros for each household affected by airport enlargement. Nonetheless among their CV study and this there are marked differences, firstly in their study relevant population is that of the Metropolitan Region of Barcelona (4.3 million people in 3,200 sq. Km), which may not be aware about what does it means to live nearby airports, consequently, it is expectable that their willingness to pay is lower that WTP 
of awareness people. Table 4 reports the models built to explain the indirect WTP. Results suggest that revalorization hypothesis increases as: 1) airplane's noise nuisance increases, 2) respondents income increases, 3) when respondent live in the area of neighborhood associations, and 4) when there is an interaction between respondent's house noise insulation and noise annoyance (multiplicative effect). According to $B$ coefficient as noise annoyance increase (in our 0-10 ordinal ad hoc scale) the value of housing, increase 1.414 Euros. When spatial interdependences are solved using a GWR models explicative power raises up to $59.7 \%$.

TABle 3 Explicative model of IndiRect-WTP (Hypothesis OF housing REVALORIZATION)

\begin{tabular}{|c|c|c|c|c|c|c|}
\hline & & MOD-R1 & MODR-2 & MODR-3 & $\begin{array}{l}\text { MODR-4 } \\
\end{array}$ & MOD-R4 GWR \\
\hline Constante & $\begin{array}{l}\text { B } \\
\text { sig. }\end{array}$ & $\begin{array}{l}1.189 \\
0,557 \\
\end{array}$ & $\begin{array}{l}1.164 \\
0,558 \\
\end{array}$ & $\begin{array}{r}-886 \\
0,651 \\
\end{array}$ & $\begin{array}{r}-1036 \\
0,598 \\
\end{array}$ & + \\
\hline Mol_vol_son & $\begin{array}{l}\text { B } \\
\text { sig. }\end{array}$ & $\begin{array}{l}1.793 \\
0,000 \\
\end{array}$ & $\begin{array}{l}1.619 \\
0,000 \\
\end{array}$ & $\begin{array}{l}1.512 \\
0,000 \\
\end{array}$ & $\begin{array}{l}1.414 \\
0,000 \\
\end{array}$ & + \\
\hline Niv_ingresos & $\begin{array}{l}\text { B } \\
\text { sig. }\end{array}$ & $\begin{array}{l}0,257 \\
0,000 \\
\end{array}$ & $\begin{array}{l}0,256 \\
0,000 \\
\end{array}$ & $\begin{array}{l}0,226 \\
0,000 \\
\end{array}$ & $\begin{array}{l}0,248 \\
0,000 \\
\end{array}$ & + \\
\hline Aisla_ruido_aero & $\begin{array}{l}\text { B } \\
\text { sig. }\end{array}$ & & $\begin{array}{l}5.632 \\
0,003 \\
\end{array}$ & $\begin{array}{l}5.780 \\
0,002 \\
\end{array}$ & & + \\
\hline Zona_asociaciones & $\begin{array}{l}\text { B } \\
\text { sig. }\end{array}$ & & & $\begin{array}{c}4.485 \\
0,005 \\
\end{array}$ & $\begin{array}{l}4.126 \\
0,001 \\
\end{array}$ & + \\
\hline Mol_vol_son Aisla_ruido_aero & $\begin{array}{l}\text { B } \\
\text { sig. }\end{array}$ & & & & $\begin{array}{r}780 \\
0,009 \\
\end{array}$ & + \\
\hline $\begin{array}{l}\text { R2 } \\
N \\
F \\
\text { sig } \\
\end{array}$ & & $\begin{array}{r}0,354 \\
226 \\
37,56 \\
0,000 \\
\end{array}$ & $\begin{array}{r}0,380 \\
226 \\
45,50 \\
0,000 \\
\end{array}$ & $\begin{array}{r}0,402 \\
226 \\
37,28 \\
0,000 \\
\end{array}$ & $\begin{array}{r}0,405 \\
225 \\
37,56 \\
0,000 \\
\end{array}$ & $\begin{array}{r}0,597 \\
225\end{array}$ \\
\hline
\end{tabular}

Variable explicada: revalorización si el nivel de ruido volviese a ser como antes de la ampliación del 2004 Casos excluidos Rev $>>$ med +2 desv es Procesamiento por pasos sucesivos

\section{CONCLUSIONS.}

As local and long haul mobility increases in contemporary metropolises the impact of noise on quality of life is progressively evident. This problem is particularly important in compact cities, where besides traffic; public spaces are intensively used, affecting the comfort and health level of mixed uses buildings, namely residents.

After the publication of the OCDE's "Fighting Noise in the 1990s Report" (1991) noise abatement has entered in the public policy agenda. Nonetheless noise abatement is a costly issue, particularly for some specific noise sources as airport, where the problem is complex because the source changes in spatial terms (reconfiguration of aerial corridors) and temporal terms (traffic increment). The keystone on the design of public policies against noise is the appraisal of potential benefits; it is to say the social value of silence. 
Environmental economics is the theoretical framework that supports the use of two extended techniques used to assess the value of non market goods or services as it is silence. Hedonic prices and contingent valuation try both to find the marginal utility of environmental assets. Using the willingness to pay (WTP), or the willingness to be compensated (WTC), VC tries to find the compensatory or equivalent variation that allows recovering the subject's utility level in environmental quality variation scenery. In this context VC uses sociological surveys as a way to collect information and econometric models as an interpretation tool.

In this paper we have used (CV) to find the marginal value of silence. Namely, this research has tried to evaluate the acoustical impact of Barcelona's airport enlargement over residential surrounding.

In the airport experiment the respondents WTP averaged 8.95 Euros/person/month. Econometric models, built on survey information and contextual information derived from socio-demographics, suggest a positive correlation between WTP and: income level, noise annoyance produced by airport, and the fact that respondents live in the spatial ambit of neighborhood associations against airport enlargement's negative effects. At the same time there is a negative association between WTP and the presence of other sources of urban noise, as motorways, which suggest a trade off, between the importance of airport noise and other sources. Those results are coherent with theory and reveal an important impact of social perception on the formation of WTP, since everything equal, WTP increases when people is gathered in activist associations. So it can be conclude that when respondents are awareness about noise source problematic they act as follows: firstly non-protest respondents state a high WTP, beyond their subjective perception of noise and annoyance; secondly, more awareness respondents have a higher protest rate, since they are knowledgeable people that are skeptical about the environmental benefit proposed in relation to the provision vehicle. This may bias average WTP underestimating the true social value of silence.

\section{BIBLIOGRAPHY.}

BARREIRO, J., M. SANCHEZ, and M. VILADRICH-GRAU. 2005. How Much are People Willing to Pay for Silence? A Contingent Valuation Study. Applied Economics. 37(11), pp 1233-1246.

BATEMAN, I. J., et al. 1995. Elicitation and Truncation Effects in Contingent Valuation Studies. Ecological Economics,. 12(2), pp 161179. 
BRISTOW, A. L. and M. WARDMAN. 2006. Valuation of Aircraft Noise by Time of Day: A Comparison of Two Approaches. Transport Reviews. 26(4), pp 417-433.

BROOKSHIRE, D. S., et al. ISSN 0002-8282. 1982. Valuing Public Goods: A Comparison of Survey and Hedonic Approaches. The American Economic Review. 72(1), pp 165-177.

CARSON, R. T., N. E. FlORES, and N. F. MEADE. 2001. Contingent Valuation: Controversies and Evidence. Environmental and Resource Economics. 19(2), pp 173-210.

CUMMINGS and OSBORNE TAYLOR, 1998. G.R., Does realism matter in contingent valuation surveys? Land Economics 74 (1998), pp. 203-215.

FABUREL, G. 2002. Évaluation Du Coût Social Du Bruit Des Avions. Application De La Méthode d'Évaluation Contingente Au Cas d'Orly. Les Cahiers Scientifiques du Transport. (42), pp 43-74.

FEITELSON, E., R. HURD, and R. MUDGE. 1996. The Impact of Airport Noise on Willingness to Pay for Residences. Transportation Research Part D: Transport and Environment. 1(1), pp 1-

FOTHERINGHAM, AS; BRUNSDON, C.; CHARLTON, M. 2002. Geographically Weighted Regression, The Analysis of Spatially Varying Relationships. Wiley, London.

GARCIA, D. and P. RIERA. 2003. Expansion Versus Density in Barcelona: A Valuation Exercise. Urban Studies. 40(10), pp 1925.

LIENHOOP, N. and D. C. MACMI LLAN. 2007. Contingent Valuation: Comparing Participant Performance in Group-Based Approaches and Personal Interviews. Environmental Values. 16(2), pp 209-232.

LEVESQUE, T. J. 1994. Modelling the effects of airport noise residential housing markets: a case study of Winnipeg International Airport. Journal of transport Economics and Policy, pp 1992-210

NAVRUD, Ståle. 2002. The State-of-the-Art on Economic Valuation of Noise, Final Report to the European Commission. Agricultural University of Norway.

NELSON, J. P. 1980. Airports and Property-Values - Survey of Recent-Evidence. Journal of Transport Economics and Policy. 14(1), pp 37-52.

NELSON, J. P. 2004. Meta-Analysis of Airport Noise and Hedonic Property Values. Journal of Transport Economics and Policy. 00038(00001), pp 1-28. 
REDONDO i TORREGROSSA, MARIA E. 2005. Impacte Del Soroll Per I'Ús De La Tercera Pista De I'Aeroport De Barcelona Sobre Gavà Mar, Projecte de Fi de Carrera, Universitat Autònoma de Barcelona.

RIERA, P. and M. MACIAN. 1999. Análisis Coste-Beneficio De La Ampliación Del Aeropuerto De Barcelona Con Externalidades Ambientales. Ruido, Polución Atmosférica y Ocupación De Humedades. Estudios sobre la Economía Española. (47), 19 pp.

SCHIPPER, Y., P. NIJKAMP, and P. RIETVELD. 2001. Aircraft noise valuation studies and meta-analysis. International Journal of Environmental Technology and Managment. 1(3), pp 317-320.

STRAZZERA, E., et al. 2003. Modelling Zero Values and Protest Responses in Contingent Valuation Surveys. Applied Economics. 35(2), pp 133-138.

THUNE-LARSEN, H. 1995. Charges on Air Traffic Noise by Means of Conjoint Analysis. Oslo: Institute of Transport Economics (TØI).

Van Praag,Bernard M. S. and B. E. BAARSMA. 2005. Using Happiness Surveys to Value Intangibles: The Case of Airport Noise. The Economic Journal. 115(500), pp 224-246.

WALTERS, A. A. 1975. Noise and Prices. Oxford University Press, London. pp 147 p. 